\title{
Evaluation of Teaching Effectiveness of Lecturers in Universities in Nigeria: The 360-Degree Perspectives
}

\author{
Umukoro Stirruph $^{1} \quad$ Shaib I. Omade ${ }^{2}$ \\ 1.Department of Business Administration and Management, School of Business Studies \\ Federal Polytechnic, Auchi Edo State \\ 2.Department of Statistics, School of Information and Communication Technology \\ Auchi Polytechnic, Auchi
}

\begin{abstract}
This paper contended among other issues that the current performance technique used to evaluate academic staff in universities in Nigeria is no longer effective in the face of the incompetence and ineptitude exhibited by lecturers in recent times. For example, research outputs are almost non existent because most lecturers have no capacities to attract research grants to themselves and to their institutions to 'produce' knowledge, technology and innovation whereas, universities are the hub for these. Some collect money for marks and demand sexual gratifications from students; they do not engage in community service which is one aspects of lecturing job. This research is carried out to evaluate lecturers in three universities using the 360-Degree Performance Evaluation Technique developed by Umukoro and Nwoko. Consequently, 30 lecturers, 150 lecturers' colleagues and 600 students were purposively selected from the universities. In addition to evaluating selected lecturers' on paper qualifications and publications they were also evaluated on dressing, temperament, punctuality, and regularity in going to classes to teach. Their level of morality and disciple were also rated. A self-evaluation questionnaire and two sets of closed-ended questionnaires were used for data collection. The instruments were validated using test and re-test method. They were also subjected to reliability test which showed that all the questionnaire items were significant $(\mathrm{P}<0.05$ at $5 \%)$ to the study. Research assistants/informants were recruited to distribute and retrieve questionnaires. Data collected were analysed with descriptive statistics using Statistical Package for Social Sciences (SPSS Version 13.0). The study findings amongst other things showed that the lecturers faired averagely in some of the variables evaluated and scored very poorly in other areas such in attracting research grants; conducting researches; and rendering community service. It was recommended amongst others that the institution studied should make efforts to ensure that their lecturers are on top of the game in aspects of academic work.
\end{abstract}

Keywords: Evaluation, Performance evaluation, 360-Degree Evaluation Technique, Lecturers.

DOI: $10.7176 / \mathrm{EJBM} / 13-20-13$

Publication date:October $31^{\text {st }} 2021$

\section{Introduction}

The over 176 federal, state and private universities in Nigeria are established to train manpower for the country (InfoGuide, 2019). Management in these institutions makes efforts daily to achieve this goal through better planning and effective management of human resources. Accordingly, one of the major concerns of these managers is how to measure the performances of lecturers in these universities.

With respect to performance evaluation, universities have many methods to choose from when selecting techniques but one technique that has gained popularity in developed countries is The 360-Degree Performance Evaluation Technique. 40\% of America companies used the technique in 1995 but by year 2000 this has jumped to $65 \%$ (Alexander, 2006 cited in Umukoro \& Nwoko, 2017). However, to the best of our knowledge, the 360Degree technique evaluation method is not yet popular in Nigeria universities even when the technique has been described as more encompassing and objective (Armstrong, 2009, Torrington, Hall, \& Taylor, 2008).

Nigeria has many universities employing thousands of lecturers to research, teach, and render community service in line with lecturers' mandate in the country. While these lecturers are growing in their careers through promotions and appointments, it can be observed that the quality of university education today has dropped when compared to the quality in the past.

Stakeholders (parents, government, employers) in the education sector have attributed the causes of this dwindling fortune of university education to parents, students, and lack of funds. The problem however could be that lecturers in the system are not doing their jobs effectively and unfortunately, the current performance evaluation method used for measuring lecturers' performance is, in our view, has become too weak to detect lecturers' inadequacies and unprofessional conducts which some lecturers have been found guilty of in recent times. For example, in the name of collaboration some lecturers do not do research and write papers; they only pay money to add their names to articles written by other lecturers and use such journal for promotion and advancement. Furthermore, lecturers appear not to have capacities to attract research grants to their institutions to 'produce' knowledge, technologies, and innovation whereas universities are the hub for the production of these. For instance, an analysis of the quality of proposals submitted by lecturers to Nigeria's Tertiary Education Trust 
Fund (TetFund) for award of research grant for the period $(2012-2019)$ showed that out of 3,356 proposals submitted by faculties, only 241 or $0.07 \%$ of them scaled through TetFund's Screening Panel due mainly to poor articulation and presentation of research proposals (TetFund' NRFS \& MC, 2020).

Unuoha (2020) has argued that promotion and appointment to positions in tertiary institutions in Nigeria are no longer based on competencies ascertained through performance evaluation; it is now based on favoritism, nepotism and subservient sycophancy. To the best of our knowledge as lecturers, the evaluation system pays too much emphasis on publications and conferences to the detriment of other variables that make quality teaching and learning possible. It could also be seen that lecturers do not dress neatly and appropriately. They only do so when going to attend a conference or academic board meetings (see Auchi Polytechnic Circular (2021, August, 11). Also, it can be argued that some lecturers have become semi-gods harassing and intimidating students and sometimes colleagues. Equally, interpersonal conflicts and unhealthy rivalries amongst lecturers are also noticeable. Interpersonal communication among co-lecturers and students are in some cases not cordial

Finally, students who are critical stakeholders in the university system do not have any input in the evaluation system; yet, they are the ones who receive the brunt of lecturers inefficiencies, ineffectiveness, harassment and some times victimization and high-handedness

This state of affairs (current evaluation system in universities) cannot continue in the face of more effective techniques like the 360 degree method which has been acclaimed to be more encompassing and objective when compared to the traditional evaluation methods (Umukoro and Nwoko, 2017; Armstrong, 2009; , Torrington, et al 2008, Adomii, 2007). It is now imperative to experiment with new evaluation technique that is elaborate enough to detect lecturers' strength and weakness.

The major aim of the study is to adopt the 360-Degree Template developed by Umukoro \& Nwoko (2017) to evaluate selected university lecturers in Edo State, South-South Nigeria. The specific objectives are to:

i) find out whether all the lecturers evaluated have requisite academic and professional qualifications to lecture in universities in Nigeria.

ii) ascertain the extent to which lecturers attract research grants; conduct researches; and the extent of their participation in community service.

iii) ascertain their regularity and punctuality in going to classes to teach students.

iv) ascertain the quality of dressing of the selected lecturers.

v) ascertain the moral standing of the selected lecturers.

vi) evaluate the quality of interpersonal communication between lecturers and students on one hand and between lecturers and their colleagues on the other hand.

The below research questions guided the study:

i) are university lecturers in Nigeria qualified academically and professionally?

ii) to what extent lecturers in Nigeria universities' attract research grants and conduct researches?

iii) do lecturers go to classes regularly and punctually?

iv) do university lecturers dress well?

v) do university lecturers have high moral standard?

vi) what is the quality of interpersonal communication between lecturers and their colleagues on the one hand and between lecturers and students on the other hand?

The Holy Bible in the Book of James 3:1 said that if there is any one to evaluate more strictly, that person is the teacher. Also, John Dewey (1859-1952), one of the earliest educational philosopher, has argued that: by the time your students are eagerly waiting with desire for you to enter their class, you are a successful teacher; by the time your class is absolutely quiet while you are delivering your lesson, you are a professional teacher; and by the time your students expose their worries and secret to you knowing that you are the closest teacher they can trust, you are a great teacher...

The study is therefore important to lecturers, students, the universities studied, policy makers, practitioners and other stakeholders in the university sub-sector. In the first place, it will help to popularize the 360-Degree evaluation technique in universities in Nigeria. Secondly, it is an attempt for the first time to involve students and lecturers in the evaluation process of academic staff in the country. Thirdly, in addition to rating lecturers based on paper qualifications, publications, conferences attended, lecturers' performances in classroom, research efforts and their behaviours as they carry out their duties were evaluated by students and their colleagues. Finally, being an exploratory study, this research may open a vista for further studies on the subject matter.

The population of the study is all the Academic Head of Departments (HODs) of universities selected for the study. They were purposely selected because the researchers assumed they must have spent considerable number of years in the system. And as HODs they interact with students and colleagues extensively. It is also assumed that students and lecturers colleagues know the selected lecturers very well to be able to evaluate them.

The study covered three universities in Edo State, South-South Nigeria. It was also limited to the objectives and research questions raised.

The study, like other human endearvours, was negatively impacted by Covid-19 Pandemic which crippled 
educational activities all over the world. For instance, the case study institutions were closed down for several months in compliance with Covid-19 protocols. Also, Academic Staff Union of Universities' strike that lasted almost a affected the study because the research population and respondents were at home.

Furthermore, the HODs who are the subject matter of the study were very reluctant to complete the selfreporting questionnaire. In fact, most of them thought that it was their institution's management that was evaluating them. In spite of repeated visits, most of them avoided the researchers by forming too busy.

The review is structures as follows: conceptual review, current evaluation system in Nigeria universities, Performance evaluation technique, the 360-Degree Technique, theoretical framework, and empirical review.

\section{Conceptual Review}

In the work place performance is taken as how well or badly an employee or groups of employees do something well or poorly (Ata, Chafik, Razane, and Elalami, 2016). From this point of view, Bhat (2020) defined performance evaluation as the management technique used to measure employees' work and results using their jobs' descriptions as benchmark. Alexander (2006) in Umukoro and Nwoko (2017) see performance evaluation as a management process which involves evaluating employees to see how they are performing or have been performing their jobs based on their job duties as benchmarks with a view to providing feedback to them. It is a measurement process of measuring employees' job performance by comparing actual results with desired outcomes with a view to remedying lapses observed.

For its functions, (Irby, 1978, Armstrong, 2009, Gareth \& George, 2003) have discussed the functions of performance evaluation in organisations but this study aligned with Nor's (2018) view that every performance evaluation policy is designed to provide an appropriate, clear, and consistent framework for the assessment of employees performance within the context of work improvement; self-evaluation and development planning. Nor further opined that it ensures that managers fairly and equitably review the performance of employees to encourage employee to deliver high quality service to stakeholders and treating colleagues with dignity and respect.

\section{Performance Evaluation Technique}

Generally, performance evaluation focuses on traits, behaviour and results. The types of evaluation are therefore categorized as follows: (1) trait appraisal, (2) behaviour appraisal and (3) results appraisal (Gareth \& George 2003, Torrington et al, 2008; Armstrong, 2009). Based on psychological and biological sciences, trait evaluation measures the degree to which employees exhibit a particular trait in relation to jobs while behavioural appraisal looks at specific actions related to a job. Result evaluation focused on outcomes (Burch, 2018).

\section{Current Evaluation Technique in Universities}

The current performance evaluation system in Nigeria universities usually starts with distribution of Annual Performance Appraisal (APA) Forms where lecturers fill in their personal data, qualifications, journals and book published where applicable; conferences attended, etc. The completed forms are then submitted to lecturers' HODs/Deans who also have portions to complete in the form and thereafter all duly completed APA are forward to higher authorities (Igbojekwe \& Ugo-Okoro, 2015). This method has been used for a very long time without modification or improvement.

The method has been criticized as follows: (1) it is carried out on lecturer every three or four years and it is for promotion purpose only; whereas performance evaluation exercise is usually aimed at identifying workers areas of strengths, weaknesses, and encourage improvement (Adoni, 2007; Armstrong, 2009 Umukoro \& Nwoko, 2017), (2) it does not evaluates the actual behaviour of lecturers (3) lecturers interpersonal communication or relationship with co-lecturers and students are not considered, (4) students who are direct consumers of lecturers' services are not formally involved in the evaluation of their teachers (Adomi 2007; Ugbojekwe \& Ugo-Okoro, 2015; Umukoro \& Nwoko, 2017). The system has also been corrupted because many lecturers have been found to have submitted plagiarized papers and falsified records (Unuoha, 2020). Furthermore, the number of research grants attracted and community services rendered by lecturers are left out yet these are main duties of academics.

\section{The 360 Degree Techniques}

The 360-Degree Evaluation Technique is one that takes into account all the inadequacies inherent in other personnel evaluation methods. It is one which evaluate trait, behaviours and outputs simultaneously (Seldin, 1980; Peiperl, 2001; Alexander, 2006; Akinyele, 2010 cited in in Umukoro and Nwoko, 2017). Like other techniques, the 360 degree method is a formalized process whereby employees are evaluated by multiple raters who regularly interact with the employees but differ from other methods because most of the time the raters are anonymous and the feedbacks are usually more objective (Armstrong, 2009).

Based on the philosophy and tenets of the 360-Degree method Umukoro and Nwoko (2017) developed a template that could be used to evaluate lecturers in tertiary institutions in Nigeria. Table 2 below presents this template. It shows who is to do the evaluation, what lecturers are to be to evaluated on, and the specific matrices 
to evaluate in the learner.

Table 2. Who Evaluate, What to Evaluate and the Metrics to Evaluate using the 360 degree technique for lecturers.

\begin{tabular}{|c|c|c|}
\hline Who Evaluate & What to Evaluate & Evaluation Metrics \\
\hline HODs/Deans/ VCs & $\begin{array}{l}\text { Qualifications and other } \\
\text { variables }\end{array}$ & $\begin{array}{l}\text { 1.Qualification (Academic and Professional) } \\
\text { 2. Teaching/lecturing experience. } \\
\text { 3. Academic publications and } \\
\quad \text { conferences attended. } \\
\text { 4. Administrative assignment. } \\
\text { 5. Loyalty to department/faculty/institution. } \\
\text { 6. Dressing* } \\
\text { 7. Temperament*. }\end{array}$ \\
\hline Lecturers colleagues & Behaviour/conduct & $\begin{array}{l}\text { 1. Quality of interpersonal communication. } \\
\text { 2. Quality of contribution at } \\
\text { department's/committee's meetings. } \\
\text { 3. Level of discipline. } \\
\text { 4. Dressing* } \\
\text { 5. Temperament*. }\end{array}$ \\
\hline Students & Behaviour/conducts & $\begin{array}{l}\text { 1. Clarity in lecture delivery. } \\
\text { 2. How well they teach. } \\
\text { 3. Regularity/Punctuality in class. } \\
\text { 4. How helpful to students. } \\
\text { 5. Moral standing. } \\
\text { 6. Dressing*. } \\
\text { 7. Temperament* }\end{array}$ \\
\hline $\begin{array}{l}\text { Employers/Stakeholders/ } \\
\text { Society }\end{array}$ & Quality of graduates & $\begin{array}{l}\text { 1. Performance at interview. } \\
\text { 2. Performance on the job. }\end{array}$ \\
\hline
\end{tabular}

Source: Adapted from Umukoro and Nwoko (2017, p. 165). "Re-designing performance evaluation technique of lecturers for higher performance", Management Science Review(8)1,

* Dressing and temperament could be evaluated by all raters simultaneously.

From Table 2, lecturers' immediate bosses (e.g. their HODs) can rate them on qualifications and other variable; while co-lecturers could rate them on interpersonal communication, quality of contributions at meetings, integrity, etc. Students can evaluate them on regularity/punctuality in classes; clarity and how well they understand their lecturers, etc Dressing and temperament could be evaluated by all raters. The feedback from these multiple raters will then be aggregated, analysed, summarized, and relayed to the learners (lecturers in this case) in an unobtrusive manner. Thereafter, action plan for training/development can be designed and implemented. The development can take the form of coaching, counseling and outright training by resource persons either from within the organisation or by external consultants (Alexander, 2006; Armstrong, 2009).

\section{Theoretical Framework}

This study was rooted on Festinger (1954) Social Comparison Theory, DeNisi and Kluger (2000) Feedback Intervention Theory, and 360 Performance Evaluation Principles. According to Cherry (2000), the social comparison theory of Festinger (1954) suggests that people have innate drive to evaluate and compare themselves often in comparison to others (in social or organizational settings). The process involve people coming together to know themselves by evaluating their own attitudes, knowledge, abilities and traits, etc. DeNisi and Kluger (2000) on the other hand, is of the view that managers typically assume that talking with employees about their evaluation outcomes and performance make it more likely that productivity and performance will improved.

The 360-Degree performance evaluation technique conceptualized by Marshall Goldsmith in 1954 is a formalized process whereby individual or groups of employees receives feedbacks from multiple raters who he/she has regularly interacted with over a period of time (Alexander, 2006).

\section{Empirical Review}

According to Torrington et al (2008), the 360-Degree technique was developed by Marshall Goldsmith in 1949. Torrington et al also noted that General Electric of America was the first organisation to use the technique but today, it is being used by Crompton Greaves, Wipro, Infosys, Reliance Industries, and other organisations in India, America and Europe (Verma, 2015). Its popularity is such that $40 \%$ of America companies used the 360-Degree Technique in 1995 but by year 2000 this jumped to 65\% (Alexander (2006).

Empirically, Bacal and Fredrick (2000) did a comparative study using one of the traditional technique and the 360 degree method. The results showed that the later yielded more reliable, objective and consistent results. 
Also when students were requested to evaluate their teachers using the 360 degree techniques, the outcomes were more revealing when compared to previous evaluations with traditional methods (Ece \& Cemal, 2015). Furthermore, Marris and Rosemary (2016) reported that since the inception of the 360 degree techniques in Kumasi Polytechnic in Ghana, performance increased consistently.

In a recent study (Sok-Foon, Sze-Yin, Yin-Fah, 2012) where students were requested to evaluate their lecturers and tutors, the outcome showed that, generally, the students agreed that their lecturers and tutor fulfilled their job scope and were willing to provide guidance $(98.0 \%)$. Lecturers and tutors start the class within first five minutes (75.3\%); lecturers and tutors were well prepared for each class session $(81.2 \%)$; class session were well organized (74.0\%); lecturers and tutors spoke clearly (72.0\%); they provide a fair and clear assessment $(73.6 \%)$; and they were willing to offer individual help $(73.0 \%)$.

Students' evaluation is now included in the key performance index for lecturers in staff appraisal and teaching effectiveness in most institutions in Europe and America (Griffin, 1999; Liaw \& Goh,,2003).

\section{Research Methodology}

Descriptive survey was adopted in the study. Consequently, purposive sampling technique was used to select 30 lecturers, 150 lecturers colleagues, and 600 students in the institutions studied. In line with Umukoro and Nwoko 360-Degree template, lecturers were evaluated by these respondents. Apart from the self-reporting questionnaire that evaluated lecturers' qualifications (academic and professional), number of publications, age, experiences, and community service, lecturers' colleagues and students evaluated them on other criteria such as dressing, temperament, morality, regularity and punctuality in going to classes, discipline and interpersonal communication amongst others. Two research assistants/informants were recruited in each of the universities under focus who helped to identified the respondents, distribute and retrieved questionnaires.

\section{Research Instrument/Instrumentation}

Three sets of structured questionnaires were the major instrument used to gather data for the study. They are: questionnaire for HODs, and questionnaire for HODs' colleagues. and students questionnaire. HODs' questionnaire has 15 questions while the other two sets of questionnaires have 11 and 15 questions respectively. These instruments validated using test and re-test method and the results were consistent. The instruments were also subjected to reliability test which showed that all the questionnaire items were significant $(\mathrm{P}<0.05$ at $5 \%)$. Also, using Cronba's Alpha correlation method, the correlated values of the HODs' colleagues and that of students questionnaires were $\mathrm{r}=0.6670$ and $\mathrm{r}=0.5680$ respectively. On the average therefore, the reliability test for the two instrument is $(0.6670+0.5680)$ divide by two (2). This gives 0.6175 or 62 per cent which suggests that the research instruments were reliable at $62 \%$

\section{Method of Data Collection}

While the researchers identified, distributed and retrieved questionnaires in one of the studied institutions, research assistants/informants did same in the other institutions. These questionnaires were personally served on all the respondents and a period of three days were given before retrieval. In one of the institution where the rate of return was low initially, distribution was repeated which yielded improvement.

\section{Method of Data Analyses}

Descriptive statistics, particularly tables and simple percentage were the major tools in used analyzing the data collected. However, a statistician was contracted to do the analysis. For speed and accuracy, Statistical Package for Social Sciences (SPSS Version 13.0) was used.

\section{Data Analyses}

Recall that three sets of questionnaires were distributed to three categories of respondents. In all, 30 lecturers, 150 lecturers' colleagues and 600 students were served questionnaires. Table I below shows the distribution of the respondents, number of questionnaires distributed, and the percentage rate of return.

Table 1: Distribution of Research Respondents

\begin{tabular}{|l|c|c|c|}
\hline Respondent & $\begin{array}{l}\text { No of questionnaire } \\
\text { distributed }\end{array}$ & $\begin{array}{l}\text { No of questionnaire } \\
\text { retrieved }\end{array}$ & $\begin{array}{l}\text { Rate of return in } \\
\text { percentage }\end{array}$ \\
\hline Lecturers (HODs) & 30 & 21 & 70 \\
\hline Lecturers' Colleagues & 150 & 110 & 73 \\
\hline Students & 600 & 448 & 75 \\
\hline
\end{tabular}

Source: Results of field survey, 2021

As Table I showed, out of 30 questionnaires were given to lecturers 21 representing $70 \%$ were successfully retrieved; of the 150 questionnaires served on lecturers' colleagues 110 representing $73 \%$ were retrieved; and out of the 600 questionnaires given to students, 448 which represents $75 \%$ were found good and used for the study. 


\section{Analyses of Lecturers' Responses}

Ninety $(90 \%)$ of the lecturers who responded were between $41-50$ years of age and $95 \%$ of them were males who are senior lecturers and above and all of them (100\%) have PhDs. Also, 70\% of them belong to at least one professional body relevant to their areas of academic disciplines. Majority (95\%) of them have been in the lecturing profession for between 16 - 20 years; while $70 \%$ of them became Heads of Department one or three years ago.

The analyses further revealed that majority $(60 \%)$ of the lecturers have published between $16-20$ journal articles but few, less than five per cent, of these articles were not based on outcomes of empirical researches (where empirical research in this study mean researches that first hand data were collected, analyzed, interpreted and findings disseminated (Ojo, 2020). On research grants, $90 \%$ of the lecturers reported that none of their work has attracted research grants. Equally, the level of participation in community service amongst the lecturers evaluated was very low - in fact, only two lecturers responded to the question on this in the questionnaire.

\section{Analyses of Colleagues' Responses}

Majority (90\%) of the lecturers' colleagues who evaluated them were males and are between 35 - 40 years of age and like the lecturers evaluated, 70\% of the colleagues have PhDs degrees and they have been evaluated lecturers' colleagues in the department for between 5 to 10 years.

These respondents have this to say on dressing of lecturers under focus: the lecturers dress very well (32\%); dress well (52\%), and do not dress well (16\%). For quality of interpersonal communication their responses were: relate very well (20\%); relate well (65\%) have relationship issues (15\%). For quality of contributions at meetings the responses were: contributes well (70\%) and do not contribute well (30\%).

On discipline which mean punctuality to work, obeying official instructions, meeting deadlines, honest financial dealings, sexual harassment, bullying students, collecting money from students for marks, sexual harassment of students and colleagues, intimidation and bullying of students, lecturers colleagues responded as follows: highly disciplined (60\%); disciplined (28\%) and not discipline (12\%). For temperament, where temperament is taken to be (how easily annoyed one can be), the opinion of this category of respondents are: occasionally temperamental ( $60 \%$ ); even tempered (30\%), and not temperamental (10\%). For leadership styles, $65 \%$ of lecturers colleagues said the lecturers surveyed are democratic, $25 \%$ said they are autocratic and $10 \%$ were neutral on this variable.

\section{Analyses of Students Responses}

The students were all in 400 level and they are between 21 - 26 years; $60 \%$ of them said the lecturers being evaluated have taught them in the past, while $40 \%$ said the lecturers are teaching them presently which showed that the students know the lecturers very well to evaluate them on the chosen criteria.

The students responses were as follows: their lecturers comes for classes very regularly 30\%); regularly (60\%); not regularly (10\%). For punctuality in coming for classes: very punctual (16\%) punctual (62\%); not punctual $(22) \%$. For how clearly the students hear and understand their lecturers when teaching, the responses are as follows: clearly hear and understand (52\%) hear and understand (48\%); and do not clearly hear and understand $(08 \%)$.

On temperament and moral standing which the lecturers' colleagues also evaluated, students' responses showed that $72 \%$ of the lecturers are not even tempered; $22 \%$ said they are occasionally temperamental while six per cent said their lecturers are highly temperamental. As for moral standing, our lecturers have very high moral standard (20\%); have high moral standard (68\%); and have low moral standard (12\%).

\section{Interpretation and Discussion of Findings}

From the analyses all the lecturers evaluated are qualified in terms of teaching qualifications and experience. They not only possessed $\mathrm{PhDs}$ which is the minimum qualifications to teach in the university but they have also gathered considerable number of experience as majority $(75 \%)$ of them have spent between $10-15$ years in the system.

The lecturers also have impressive number of journal publications (between 16-20 journal articles), however, only few of these publications, less than five per cent, were research based articles. That is, articles based on outcomes of research efforts. This appears to reflect the reality because it can be seen that no much research efforts are going in Nigeria universities (Umukoro \& Nwoko, 2017); emphasis is laid heavily on teaching and administration. Furthermore $90 \%$ of the lecturers reported that they have not attracted research grants for once. This supports the finding above that not many of their published works were outcomes of research findings. This is not surprising because most research proposals that attract grants are usually empirical. Also,S it has been established that most lecturers in Nigeria have not mastered the knowledge and skills to write a fundable research proposal (TetFund's National Research Fund Screening and Monitoring Committee Report (April, 2011).

Lecturers' responses on community service were not impressive. In fact, only two of the lecturers surveyed responded to this question in the questionnaire. Again, this is not unexpected because most universities in Nigeria do not emphasize community service as part of lecturers' jobs. Like research, community service is highly 
neglected in favour of teaching (Umukoro \& Nwoko, 2017; Igbojekwe \& Ugo-Okoro, 2015).

In terms of dressing which lecturers' colleagues also evaluated, majority of lecturers' colleagues (56\%) and most of the students' (54\%) responses' corroborated themselves. As can be seen they agreed that the lecturers evaluated dress well but not very well. No doubt these are pass marks but the data suggest that there is still room to improve on their dressing because $50-59 \%$ in academic circles is an average score. In fact, it is a "C"grade which means that lecturers surveyed do not dress very well. This may not be far from the reality because it is not unusual to see some lecturers dress shabbily and inappropriately with bushy hair and beard as though they are going to farm. You only see them dress very well during academic conferences or when going to attend academic board meetings. Even at this, some still dress inappropriately by mixing Native and English dressing patterns.

For temperament, the lecturers colleagues' and students' responses differ widely. While $75 \%$ of the former rated the lecturers as not temperamental only $42 \%$ of the later rated them this way. It can be seen that students perception of lecturers' temperament is poor because some lecturers are not friendly to students, they are not patient with them and some do send students out of their classes for bad behaviours. Similar to the ratings on temperament, majority of lecturers colleagues $(59 \%)$ and of students $(41 \%)$ respectively rated the lecturers as disciplined. What this suggest is that lecturers could appear disciplined in the perception of their colleagues but this may not be the case with students who interact with them frequently.

For regularity and punctuality the lecturers were rated well by the students. Their ratings of $60 \%$ and $62 \%$ in going to classes to teach regularly and punctually respectively were impressive but it is near perfect yet. It suggests therefore there is still room for improvement. And in terms of leadership style, $80 \%$ of co-lecturers agreed that the HODs are democratic in their leadership behaviours.

\section{Conclusion}

These statistics on the variables evaluated, taken together, suggest that lecturers fared averagely when compared to Sok-Foon, Sze-Yin, and Yin-Fah (2012) similar study where students agreed that their lecturers and tutors fulfilled their job scope and willing to provide guidance and supports $(73.0 \%)$, lecturers and tutors start the class within first five minutes (73.3\%); they were well prepared for each class session $(81.2 \%)$; they spoke clearly in class (72.0\%); class session was well organized (74.0\%); they provide fair assessment (73.6); and they were willing to offer individual help (73.0\%).

To the best of the researchers' knowledge, this study is the first of its kind in the Nigeria academic landscape. As noted earlier, students and lecturers are made to evaluate lecturers. Though the scope of the research is limited due to finance the findings nevertheless, in our view, is insightful. Therefore, it is high time tertiary institutions in Nigeria experimented with 360-Degree evaluation technique where stakeholders in the system are integrated into the evaluation technique because, for example, students know lecturers more than management do just as the lecturers know themselves more than management know them. The 360-Degree technique is encompassing and always yields unbiased results that are not usually contested by those evaluated. Therefore, it will not be out of place to involve lecturers and students in the evaluation of faculties.

\section{Summary of Findings}

From the analyses and discussion, the following are the major findings of the study:

1. The lecturers surveyed were not only qualified academically and professionally they also have considerable experiences in the system.

2. Most of the lecturers surveyed are even tempered.

3. The lecturers do not have communication problem. They relate well with colleagues; contribute well at meetings' deliberations, and they are democratic in their leadership styles.

4. Most students clearly hear and understand their lecturers when teaching.

5. They are disciplined but not too much of it in the perception students.

6. They also have impressive number of publications but not many of them are outcome of empirical studies.

7. Majority of the lecturers surveyed have not attracted research grants for once in spite of their impressive number of years and journals they have put in and published respectively.

8. The surveyed lecturers dress well but there is still room for improvement.

9. The moral standing of the lecturers is not too impressive in the perception of the students.

\section{Recommendations}

The focus of any evaluation is on how employees can improve, and what they need to do to be better. Flowing from the findings and discussion in this research the following recommendations are made:

1. A more embracing performance evaluation system like the 360-Degree techniques should be used in evaluating academic staff.

2. It is high time students and lecturers themselves are involved in the evaluation of lecturers.

3. Lecturer should be encouraged to attend training on how to write award-winning proposal like the 
one organized by Lift Above Poverty Institute (LAPO) recently.

4. Lecturer should be highly encouraged through provision of research grants to carryout empirical research.

5. Lecturers should be encouraged to improve on the following: dressing, discipline, punctuality, and regularity in class.

6. Public address system should be provided for lecturers to make them more audible to students in classes that are large.

We are grateful to Nigeria Tertiary Education Trust Funds (TETFUND) and Federal Polytechnic, Auchi, Edo State for making fund available for execution of the study.

\section{References}

Adomi, E. (2007). "Publication in foreign journals and promotion of academics in Nigeria. Learned Publishing $16(4), 259-263$.

Akinyele, S. T. (2010). "Performance appraisal systems in private universities in Nigeria: A study of Crowford university, Igbesa, Nigeria" Global Journal of Management and Business Research, 10(16), 60 - 72.

Alexander, D. M. (2006). "How 360-degIree performance review affect employees attitudes, effectiveness and performance?" Schmidt Labour Research Centre, Seminar Research Series, 3-11.

Armstrong, M. (2009). Armstrong's Handbook of Human Resource Management Practice (11 ${ }^{\text {th }}$ ed.), Kogan Page, London.

Ata, G., Chafik, O., Razane, C. and Elalami (May 16, 2016). "Performance: a concept to define" LOGISTICA. Doi: 10.02405712.hoo Retrieved October, 2020.

Bacal, G. and Fredrick, H. (2000). "Performance appraisal based on self-review", Personnel Psychology 21, 30 42.

Bhat, A. (2020). "PE-Definition, method, survey questions and example", QuestionPro, https:/questionprocom.cdn.ampproject.org retrieved October 15, 2020.

Burch, J. (2018). "Behaviour vs trait appraisal," https://your businesazcentral.com retrieved October 15, 2020.

Cherry, K. (2020). "Social comparison theory in psychology" https//www.verywellmind.com Accessed 10 July, 2020.

DeNisi, A.S. and Kluger (2000). "Feedback effectiveness: Can 360 degree appraisal be improved? Academy of Management Perspectives 14(1), 129 - 139.

Ece, W. and Cemal, P. (2015), “360 degree feedback and organizational culture”, London, Institute of Employment Studies.

Gareth, R. and George, J. M. (2003). Contemporary Management (3 $3^{\text {rd }}$ ed.), McGraw-Hill, Irwin, USA.

Griffin, G. A. (1999). "The education of teachers", Ninety-eight Yearbook for the National Society for the Study of Education, Part I, Chicago

Igbojekwe, A. and Ugo-Okoro, A. (2015). "Performance evaluation of academic staff in universities and colleges of education in Nigeria: The missing criteria”, International Journal of Education and Research (3), March, $627-640$.

Irby, D.M. (1978). Clinical faculty development. McGraw Hill, New York.

James 3:1 The Holy Bible, King James Version, P 289.

Liaw, S.H., and Goh, K. L. (2003). "Evidence and control of biases in Student Evaluation of teaching", International Journal of Educational Management, 17(1), 37-47.

Marris, F. and Rosemary, W. (2016). "Evaluating employees performance”, Chicago, Illinois, Public Press.

National Research Fund Screening and Monitoring Committee (April, 2020). "Tertiary Education TrustFund 2020 National Research Fund (NRF) Grant Cycle, p. 6 - 7.

Nor (2018). "Evaluation news: perspectives for a good evaluation function", http://www.norad.no accessed $17^{\text {th }}$ August, 2021.

Onuoha, C. (2020, June 20). "Radical solutions to educational crises in Nigeria", The Academy of Nigeria online Platform (The Telegram, retrieved July 2.

Peiperl, M. A. (2001). Getting 360-Degree feedback right. Harvard Business Review, 142 - 147.

Seldin, P. (1980). "Successful faculty evaluation programmes. A practical guide to improve faculty performance and promotion/tenure decision", Coventry Press, Curgers.

Sok-Foon, Y., Sze-Yin, J.H., and Yin-Fah, B.C. (2012). "Students evaluation of lecturer performance among private university", Canadian Social Science, 8(4), 238-245.

Verma, S. (2015). “360 Degree Appraisal, General Electric six parties, Retrieved October 16, 2020.

Umukoro, S. and Nwoko, G. C. (2017). Re-designing performance evaluation of lecturers for higher performance in Nigeria Universities, Management Science Review 8(1), 165 - 175.

Torrington, D. Hall, L. and Taylor, S. (2008).Human Resource Management, England,Pearson Education Limited. 